\title{
The short term visual, refractive and Topographic outcome of Corneal Collagen Crosslinking in Keratoconus
}

\author{
Renuga Devi Kaliaperumal', Amudha Purushothaman², Thiruvengada Krishnan³, \\ Shivananda ${ }^{4}$
}

${ }^{1}$ Assistant Professor, Department of Ophthalmology, Sri Manakula Vinayagar Medical College, ${ }^{2}$ Assistant Professor, Department of Ophthalmology, Indira Gandhi Medical College, ${ }^{3}$ Professor and Head, ${ }^{4}$ Consultant, Cornea Clinic,

Aravind Eye Hospital, Puducherry, India

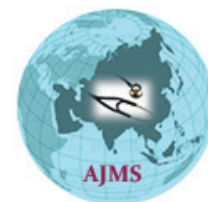

\section{A B S T R A C T}

Background: Keratoconus is a condition characterized by biomechanical instability of cornea presenting in a progressive asymmetry and bilateral way. Corneal collagen crosslinking with riboflavin and UVA is a technique that has influenced the treatment of Keratoconus by arresting the progression. Aims and Objectives: The aim of the study was to assess the short-term efficacy and safety of collagen cross-linking in Keratoconus. Materials and Methods: This prospective, nonrandomized, interventional case study was conducted at Aravind Eye hospital and PGI, Puducherry from June 2012 to April 2013. Statistical analysis was done using repeated measures ANOVA and Bonferonn's using IBM SPSS Inc. 20.Version. Results: A total of 30 patients were enrolled in this study and standard cross linking procedure was done. It was found that UCVA, BSCVA both improved about $40 \%$. Spherical Equivalent reduced by $0.7 \mathrm{D}$, cylinder reduced by $0.8 \mathrm{D}$ and total astigmatism decreased by about $0.4 \mathrm{D}$. Steepest $\mathrm{K}$ value reduced by $2 \mathrm{D}$, Irregularity and astigmatism at 3 and $5 \mathrm{~mm}$ also changed significantly $(P<0.05)$. Conclusion: Collagen cross-linking arrests the progression of Keratoconus. It seems to improve the UCVA and BCVA and it is a safe and effective procedure.

Key words: Keratoconus; Collagen cross linking; Riboflavin; UVA irradiation

\section{Access this article online}

Website:

http://nepjol.info/index.php/AJMS DOI: $10.3126 /$ ajms.v12i11.38768

E-ISSN: 2091-0576

P-ISSN: 2467-9100

Copyright (c) 2021 Asian Journal of Medical Sciences

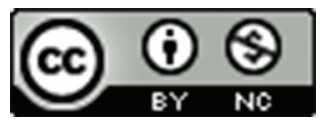

This work is licensed under a Creative Commons Attribution-NonCommercial 4.0 International License.

\section{INTRODUCTION}

Keratoconus is a condition characterized by biomechanical instability of cornea presenting in a progressive asymmetry and bilateral way. ${ }^{1}$ In $20-25 \%$ of Keratoconus patient's severe visual deterioration occurs due to irregular astigmatism, myopia, and corneal scarring. Visual rehabilitation is not provided by spectacles or RGP contact lenses. The technique of corneal collagen cross-linking with riboflavin and UVA irradiation strengthens corneal tissue. ${ }^{2-5}$ Riboflavin works as a photo-sensitizer and induces cross-linking between collagen fibrils. It also protects the cornea from UVA penetration by acting as a shield. ${ }^{2}$ Cross-linking has an arresting effect in the progression of Keratoconus. ${ }^{1}$ A small regression may occur which may be explained as an effect of rearrangement of the corneal lamellar and surrounding matrix. ${ }^{1}$ Due to increasing cross-links sites stiffer fibrils and lamellae are generated. This results in the reduction of corneal curvature. Cross-linking of human collagen is a physiologic process.

The aim of this prospective non-randomized study was to evaluate the efficacy and safety of collagen cross-linking in progressive Keratoconus on a short-term basis.

\section{Aims and objectives}

The aim of the study was to assess the short-term efficacy and safety of collagen cross-linking in Keratoconus. 


\section{MATERIALS AND METHODS}

The study was approved by the Institutional Review Board as well as the Ethical committee. It was conducted in accordance with the principles in the Declaration of Helsinki.

Patients attending the Cornea Department of Aravind Eye Hospital, Pondicherry, India with progressive Keratoconus and who were willing to come for follow-up as per the study requirement were included in the study. Progression was assessed from history and previous records. Thirty patients who met the inclusion criteria were recruited. Informed consent was obtained.

\section{Inclusion criteria}

Patients in the age group of $>16$ years with progressive Keratoconus, minimum corneal thickness of $>400 \mu$, and Keratometry of $<60 \mathrm{D}$ both male and females were included in the study.

\section{Exclusion criteria}

Patients with corneal thickness of $<400 \mu$, advanced Keratoconus with apical scar, Keratometry $>60$ D, ocular inflammatory disease, or corneal inflammatory disease were excluded from the study. Pregnant and lactating females, previous intraocular surgery, and posterior segment pathology were also excluded.

All patients or the legal guardians (in patients $<18$ years) received a detailed explanation and underwent a complete preoperative ophthalmological examination which included the following:

Visual acuity measurement by Snellen chart and refraction by Retinoscopy to assess the BCVA.

Intraocular pressure using a Goldman Applanation tonometer.

Anterior segment evaluation to be done using a slit lamp bimicroscopy.

Slit-lamp $90 \mathrm{D}$ biomicroscopy and Indirect Ophthalmoscopy to rule out posterior segment pathology.

Topography using Bausch and Lamb Orbscan.

Endothelial cell status was assessed with Konan Noncon Robo Specular microscope.

The cross-linking was performed at Aravind Eye Hospital, a tertiary eye care center in Pondicherry, India. Surgical protocol was standardized. All surgeries were performed by a single surgeon. Under GA and aseptic conditions, a $9.5 \mathrm{~mm}$ the epithelial defect was created using $90 \%$ Isopropyl alcohol. $0.1 \%$ Riboflavin was then applied for every $2 \mathrm{~min}$ for $30 \mathrm{~min}$. Anterior chamber greenish haze was confirmed using hand-held slit lamp. UVA irradiation was performed using an optical system consisting of an array of seven UVA diodes with a potentiometer in series to allow for the regulation of voltage. Irradiance was performed for $30 \mathrm{~min}$ using $3 \mathrm{~mW} / \mathrm{cm}^{2} \mathrm{~g}$ irradiation at a working distance of $6 \mathrm{~cm}$. Riboflavin was applied for every $2 \mathrm{~min}$. At the end of the procedure, antibiotic was instilled and a Bandaged contact lens (BCL) was applied. Postoperatively patients were treated with Tablet. Ciprofloxacin $500 \mathrm{mg}$, and topical antibiotic (Vigamox) and tear substitute (Refresh Tears). BCL was removed on the $3^{\text {rd }}$ or $5^{\text {th }}$ post-operative day and patients were discharged.

Patients were asked to come for follow-up in the $1^{\text {st }}$ week, $1^{\text {st }}$ month, $3^{\text {rd }}$, and $6^{\text {th }}$ months.

Each visit, refraction, BCVA (glasses or contact lens), intraocular pressure (Goldman applanation tonometer), and Slit-lamp examination for any surgery-related complications was done. Specular microscope (Konan Noncon Robo) and Topography using Bausch and Lamb Orbscan was done on the $3^{\text {rd }}$ and $6^{\text {th }}$ months. Cross-linking effect was quantified taking the maximum $\mathrm{K}$ value of the apex, maximum-minimum $\mathrm{K}$ values in the $3.0 \mathrm{~mm}$ zone of topography, astigmatism, and BCVA. The changes were estimated by comparing with previous values. Statistical analysis was done by using repeated measures ANOVA and Bonferroni's using IBM SPSS Inc. 20.Version.

\section{RESULTS}

A total of 30 patients were included in the study. Out of 30 patients, there were 18 females and 12 males. The mean age of the group studied was $20.77 \pm 5.51$ (Table 1).

Efficacy of collagen cross-linking in Keratoconus was assessed on the basis of estimating visual outcome and the topographic change in the cornea. Improvement in vision was assessed by comparing pre and post-operative changes in spherical equivalent, UCVA, BCVA, and total cylinder. The study showed improvement in the spherical equivalent preoperative value of -4.021 to postoperative value $-3.267(\mathrm{P}=0.003)$. Total cylinder decreased gradually by about $0.8 \mathrm{D}(\mathrm{P}=013)$ in 6 months. UCVA improved by 1 line in about $40 \%$ and in about $20 \%$ of patients it remained stable. BSCVA improved by 1 line in about 47\% and remained stable in about $60 \%$ (vision was recorded by Snellen's and converted to decimal form) (Table 2). 
The topographic change in the cornea was assessed by Orbscan II, taking into consideration total astigmatism, Steepest $\mathrm{K}$ value, Astigmatism, and irregularity at 3 and $5 \mathrm{~mm}$. Pachymetry was also included to observe the reduction in corneal thickness. The total astigmatism decreased by about $0.4 \mathrm{D}$ (P value) in the $6^{\text {th }}$ month follow-up. Steepest K was observed to reduce by about 2 $\mathrm{D}$ (P value). Astigmatism at $3 \mathrm{~mm}$ decreased by $0.4 \mathrm{D}$ and at $5 \mathrm{~mm}$ decreased by about $0.1 \mathrm{D}$. Irregularity at $3 \mathrm{~mm}$ and $5 \mathrm{~mm}$ was found to decrease significantly (5.07-4.4 and 5.3-4.8 respectively). Pachymetry decreased gradually from $440 \pm 4.23 \mathrm{SD}$ to $353 \pm 8.21 \mathrm{SD}$ in the $6^{\text {th }}$ month. From the study it is found that there is a decrease in cell count in first 3 months which further decreased in $6^{\text {th }}$ month. Moreover, this decrease is statistically significant $(\mathrm{P}=0.001)$ (Table 3$)$.

In all the 30 patients the epithelial defect healed, except in 5 patients in whom there was delay in healing of more than 3 weeks. In two patients there was minimal corneal haze which persisted in the $6^{\text {th }}$ month follow-up, but the vision was stable. There were no major complications such as scarring, corneal melt, or keratitis.

\section{DISCUSSION}

The main purpose of this study is to evaluate the efficiency of collagen cross-linking in arresting the progression of Keratoconus. This treatment arrests the progression of corneal thinning and ectasia by significantly increasing

\begin{tabular}{lcc}
\multicolumn{3}{l}{ Table 1: Demography of study participants } \\
\hline Age & Mean & Number \\
\hline 16-38 years & $20.77 \pm 5.51$ & 30 \\
Sex & & \\
$\quad$ Female & $20.67 \pm 5.20$ & $18(60 \%)$ \\
Male & $20.92 \pm 6.10$ & $12(40 \%)$ \\
\hline
\end{tabular}

collagen crosslink bonds and thereby, the biochemical strength of the cornea.

The efficiency parameters in our study were the visual outcome and the change in corneal curvature. In the study, it is found that UCVA, BSCVA both improved by 1-2 Snellen in about 40\%. Spherical Equivalent reduced by $0.7 \mathrm{D}$ and cylinder reduced by $0.8 \mathrm{D}$. When evaluating the change in corneal curvature the total Astigmatism is found to decrease by about $0.4 \mathrm{D}$. Steepest $\mathrm{K}$ value reduced by $2 \mathrm{D}$, Irregularity and astigmatism at 3 and $5 \mathrm{~mm}$ also changed significantly $(\mathrm{P}<0.05)$.

Thus, from our study, it is clear that the refractive status of the patients remained stable or improved slightly. Furthermore, there was a slight flattening of corneal curvature which was evident in the $6^{\text {th }}$ month postoperative period. When we look into literature, there is a similar study conducted by Agarwal, ${ }^{10}$ who studied the results of C3R in Indian eyes for a period of 1 year. His study showed that there was an improvement in BSCVA by 1 line, decrease in astigmatism, and Max $\mathrm{K}$ value. In addition, he included wavefront analyzer, which did not show much change in the spherical and high order aberrations.

There are similar studies conducted outside India. The Dresden clinical study conducted by Wollensak et al., has shown that the treated eyes showed no progression. There was a slight reversal and flattening of Keratoconus upto 2.8D. BSCVA improved by 1.4 lines. $^{3-5}$

Jankov et al., ${ }^{1}$ showed that collagen cross-linking was effective in halting progression of keratoconus and also revealed reduction in max $\mathrm{k}$ reading of more than $2 \mathrm{D}$. In his study postoperative spherical equivalent was reduced by $>1 \mathrm{D}$ and no eyes lost any line of BCVA. There

Table 2: Comparison of pre and postoperative vision and refraction

\begin{tabular}{lcccc}
\hline Estimated marginal means & Spherical equivalent & Total cylinder & UCVA & BCVA \\
\hline Pre op & $-4.021 \pm 0.405$ & $-3.330 \pm 0.373$ & $0.863 \pm 0.038$ & $0.342 \pm 0.026$ \\
3 months post op & $-3.659 \pm 0.380$ & $-2.706 \pm 0.322$ & $0.822 \pm 0.042$ & $0.271 \pm 0.024$ \\
6 months post op & $-3.267 \pm 0.395$ & $-2.444 \pm 0.298$ & $0.739 \pm 0.051$ & $0.194 \pm 0.019$ \\
P value & 0.003 & 0.013 & 0.002 & 0.000 \\
\hline
\end{tabular}

\section{Table 3: Comparison of pre and postoperative topographic values}

\begin{tabular}{|c|c|c|c|c|c|c|}
\hline Duration & $\begin{array}{c}\text { Total } \\
\text { Astigmatism }\end{array}$ & $\begin{array}{l}\text { Steep K } \\
\text { value }\end{array}$ & $\begin{array}{l}\text { Astigmatism at } \\
3 \text { and } 5 \mathrm{~mm}\end{array}$ & $\begin{array}{l}\text { Irregularity at } \\
3 \text { and } 5 \mathrm{~mm}\end{array}$ & Pachymetry & $\begin{array}{l}\text { Endothelial } \\
\text { cell count }\end{array}$ \\
\hline Pre op & $5.411 \pm 0.499$ & $52.229 \pm 0.791$ & $\begin{array}{l}4.443 \pm 0.372 \\
2.463 \pm 0.217\end{array}$ & $\begin{array}{l}5.072 \pm 0.321 \\
5.397 \pm 0.324\end{array}$ & $\begin{array}{c}440.264 \\
\pm 4.235\end{array}$ & $\begin{array}{c}2460.083 \\
\pm 33.210\end{array}$ \\
\hline $\begin{array}{l}\text { Post op } \\
3 \text { months }\end{array}$ & $4.898 \pm 0.484$ & $51.450 \pm 0.740$ & $\begin{array}{c}4.182 \pm 0.356 \\
2.408 \pm 0.223\end{array}$ & $\begin{array}{l}4.717 \pm 0.319 \\
4.910 \pm 0.355\end{array}$ & $\begin{array}{l}405.806 \\
\pm 8.709\end{array}$ & $\begin{array}{c}2303.264 \\
\pm 28.774\end{array}$ \\
\hline $\begin{array}{l}\text { Post op } \\
6 \text { months }\end{array}$ & $4.780 \pm 0.466$ & $50.869 \pm 0.689$ & $\begin{array}{c}4.057 \pm 0.329 \\
2.27 \pm 0.218\end{array}$ & $\begin{array}{l}4.469 \pm 0.301 \\
4.811 \pm 0.282\end{array}$ & $\begin{array}{c}354.778 \\
\pm 8.139\end{array}$ & $\begin{array}{c}2172.875 \\
\pm 23.638\end{array}$ \\
\hline
\end{tabular}


was no decrease in endothelial cell count and absent or even partial reversal of Keratoconus. Trazza et al., ${ }^{11}$ had studied the intra-operative as well post-operative results, in which the UCVA and BCVA improved significantly with $\mathrm{P}=0.048$ and $<0.01$ respectively Spherical Equivalent also decreased significantly. Mean baseline flattest and simulated keratometry also decreased. Similar results were reported by Caporossi et al., ${ }^{6,12}$ Spoerl et al., ${ }^{7}$ and Wittig-Silva et al. ${ }^{9}$

Regarding the safety of C3R a study conducted by Spoerl et al., ${ }^{8}$ reported that after corneal X-linking, the stroma is depopulated of keratocytes to about $300 \mathrm{~mm}$ deep. Repopulation of this area takes up to 6 months. When the cornea treated has a minimum thickness of $400 \mathrm{~mm}$ (as recommended), the corneal endothelium and even deeper structures such as lens and retina will not experience damage. The safety of this procedure was analyzed based on the complications of the procedure. From the study, it was found that there was a decrease in cell count in the first 3 months and in the $6^{\text {th }}$ month. This decrease is statistically significant ( $\mathrm{P}=0.001$ ), which accounts to about $11 \%$. Similar decrease was found in study by Vinciguerra et al., ${ }^{11}$ but on follow-up for 1 year, the count became near normal. In addition, other studies have mentioned that $10 \%$ loss of endothelial cells is acceptable. Hence our study shows that the procedure is safe.

Thus from above studies, collagen cross-linking seems to be a safe and effective procedure. Our results are also similar to studies done on long-term outcome of C3R. ${ }^{13-16}$

\section{Limitation of the study}

The major limitation in our study is the duration of followup. In most of the studies, the patients were studied up to a period of 1 or 2 years. Long term effect of C3R in keratoconus needs to be assessed by a follow-up of minimum 1 year.

\section{CONCLUSION}

From the above study, it is found that Collagen crosslinking arrests the progression of Keratoconus. It improves the UCVA and BCVA. It is a safe and effective procedure and there are no permanent side effects. There are considerable clinical benefits from $\mathrm{X}$-linking treatment and it may stabilize or even improve other clinical disorders that significantly impair the visual function.

\section{REFERENCES}

1. Jankov li MR, Jovanovic V, Delevic S and Coskunseven E. Corneal collagen cross-linking outcomes: Review. Open Ophthalmol J. 2011;5:19-20.

2. Spoerl E, Huhle M and Seiler T. Induction of cross-links in corneal tissue. Exp Eye Res. 1998;66(1):97-103.

https://doi.org/10.1006/exer.1997.0410

3. Wollensak G, Spoerl E and Seiler T. Riboflavin/ultraviolet-Ainduced collagen crosslinking for the treatment of Keratoconus. Am J Ophthalmol. 2003;135(5):620-627.

https://doi.org/10.1016/s0002-9394(02)02220-1

4. Wollensak G, Spoerl E and Seiler T. Treatment of keratoconus bycollagen cross linking. Ophthalmologe. 2003;100:44-49.

5. Wollensak G. Crosslinking treatment of progressive keratoconus: New hope. Curr Opin Ophthalmol. 2006;17(4):356-360. https://doi.org/10.1097/01.icu.0000233954.86723.25

6. Mazzotta C, Balestrazzi A, Traversi C, Baiocchi S, Caporossi T, Tommasi $\mathrm{C}$, et al. Treatment of progressive keratoconus by riboflavin-UVA-induced cross-linking of corneal collagen: Ultrastructural analysis by Heidelberg Retinal Tomograph II in vivo confocal microscopy in humans. Cornea. 2007;26(4):390-397. https://doi.org/10.1097/ico.0b013e318030df5a

7. Spoerl E, Mrochen M, Sliney D, Trokel S and Seiler T. Safety of UVA-Riboflavin cross-linking of the corneal. Cornea. 2007;26(4):385-389.

https://doi.org/10.1097/ico.0b013e3180334f78

8. Wittig-Silva C, Whiting M, Lamoureux E, Lindsay RG, Sullivan LJ and Snibson GR. A randomized controlled trial of corneal collagen cross-linking in progressive keratoconus: Preliminary results. J Refract Surg. 2008;24(7):S720-S725. https://doi.org/10.3928/1081597x-20080901-15

9. Agrawal VB. Corneal collagen cross-linking with riboflavin and ultraviolet-a light for keratoconus: Results in Indian eyes. Indian J Ophthalmol. 2009;57(2):111-114. https://doi.org/10.4103/0301-4738.44515

10. Vinciguerra $P$, Albè E, Trazza $S$, Rosetta $P$, Vinciguerra $R$, Seiler $T$ and Epstein D. Refractive, topographic, tomographic, and aberrometric analysis of keratoconic eyes undergoing corneal cross-linking. Ophthalmology. 2009;116(3):369-378. https://doi.org/10.1016/j.ophtha.2008.09.048

11. Caporossi A, Baiocchi S, Mazzotta C, Traversi C and Caporossi T. Parasurgical therapy for keratoconus by riboflavinultraviolet Type A rays induced cross-linking of corneal collagen: Preliminary refractive results in an Italian study. J Cataract Refract Surg. 2006;32(5):837-845.

https://doi.org/10.1016/j.jcrs.2006.01.091

12. Subasinghe SK, Ogbuehi KC and Dias GJ. Current perspectives on corneal collagen crosslinking (CXL). Graefes Arch Clin Exp Ophthalmol. 2018;256(8):1363-1384.

https://doi.org/10.1007/s00417-018-3966-0

13. Iqbal M, Elmassry A, Badawi AE, Gharieb HM and Said OM. Visual and refractive long-term outcomes following standard cross-linking in progressive keratoconus management. Clin Ophthalmol. 2019;13:2477-2488.

https://doi.org/10.2147/opth.s232954

14. Greenstein SA, Shah VP, Fry KL and Hersh PS. Corneal thickness changes after corneal collagen crosslinking for keratoconus and corneal ectasia: One-year. J Cataract Refract Surg. 2011;37(4):691-700.

https://doi.org/10.1016/j.jcrs.2010.10.052

15. Hashemi H, Seyedian MA, Miraftab M, Fotouhi A and Asgari S. Corneal collagen cross-linking with riboflavin and ultraviolet a irradiation for keratoconus: Long-term results. Ophthalmology. 2013;120(8):1515-1520.

https://doi.org/10.1016/j.ophtha.2013.01.012 
Authors Contribution:

RD - Principle investigator, Concept and design of the study, literature search, data acquisition and manuscript draft preparation; AP - Statistical analysis;

TVK - Definition and intellectual content, concept and literature search; SA - Intellectual concept and manuscript editing.

Work attributed to:

Aravind Eye Hospital, Puducherry, India.

Orcid ID:

Dr. Renuga Devi K - id https://orcid.org/0000-0002-7948-7557

Dr. Amudha Purushothaman - (D) https://orcid.org/0000-0002-6211-8579

Source of Support: Nil, Conflict of Interest: None declared. 